\title{
A Key? Conflict, and the Struggle for an Ecology of Dialogue, Learning and Peace among Israeli Jewish and Palestinian Educators
}

\author{
Alan Bainbridge and Linden West
}

\begin{abstract}
This chapter is about the potential for using auto/biographical narrative enquiry in teaching and research to build small ecologies of learning, healing, dialogue and peace across trauma, and profound difference. This as part of an educational project to encourage active citizenship and democratic values in teacher education in Israel, among Palestinian and Jewish educators. Auto/biographical narrative workshops and research were used to chronicle common experiences of trauma, hurt and insecurity within the unresolved conflict between Israel and Palestine. Here the other, for many Palestinians, is the Israeli Jewish coloniser over 70 years and more. For Israeli Jews, the other can be perceived as a would-be terrorist, uncivilised and bringing danger to the democratic, metropolitan light of Israel. The darkness of two unresolved traumas hangs over the work - the Holocaust for Jews and Al Nakba for Palestinians. The former is the murder of 6 million Jewish people in Europe during the and World War. The latter, in English, means the Catastrophe: of the 1948 War with the putative state of Israel, and of dispossession and loss. How much can auto/biographical and narrative processes create small ecologies of light, hope and justice? The answer is not easy, but the effort worthwhile, if the alternative is continuing cycles of hatred and violence.
\end{abstract}

\section{Keywords}

trauma - violence - auto/biography - narrative - dialogue - learning - healing and peace

The tragedy of ... so many post-colonial experiences, derives from the limitations of the attempts to deal with relationships that are polarized, radically uneven, remembered differently. The spheres, the sights of intensity, the agendas, and the constituencies in the metropolitan and ex-colonial

(C) ALAN BAINBRIDGE AND LINDEN WEST, 2021 | DOI: 10.1163/9789004465916_009 
worlds appear to overlap only partially. The small area is perceived as common does not, at this point, provide for more than what might be called a rhetoric of blame (original emphasis)

SAID (1994, p. 19)

This chapter draws on auto/biographical narrative research and forms of adult education designed to foster empathy, risk taking, storytelling, dialogue and hope across profound difference. We describe and illuminate the use of 'psychosocial' perspectives and auto/biographical narrative adult education and research among groups of Israeli and Palestinian teacher educators living and working in the State of Israel. This is against the backcloth of two profound traumas: the Holocaust and, less well known, Al Nakba (or the Catastrophe, the forced evacuation of many Palestinians from their lands and communities, in the 1948 War and since). What may be colonialist oppression, intolerance, and violence against the Palestinians continues. The word trauma is chosen deliberately, begging questions as to its effects in the past and present, and the conditions in which it might be transcended in struggles for peace.

Jacqueline Rose (2019) has challenged the view that the Holocaust represents history, while Al Nakba is firmly contemporary in people's lives. The effects of past trauma, she suggests, drawing on psychoanalytic perspectives, are visited on present and future generations, for both peoples. It is the failure, she insists, however difficult, of Israeli Jews to process the deepest experience of trauma that drives what is oppressively done in their name, here and now.

How much can adult education of an intensive, in-depth therapeutic kind, address these issues is a basic question of our chapter. We sought to create good enough, playful and experimental spaces for generating stories, and a culture of listening to self, and the other; to move beyond a rhetoric of blame in Said's (1994) compelling words. To create, in short, a kind of ecology of life for some learning and healing. We were not there to smooth over difference but to engage with it, when possible, in manageable and developmental if also inevitably restricted ways. We wanted to identify common experience and to use this as a site for reflexivity, dialogue and self/other recognition. But we struggled to transcend silence and silencing. We wanted in fact to build a larger project, to include Palestinian educators living in the Palestinian Authority 
and Gaza as well as in the State of Israel. We failed. Perhaps it reflected naivety and lack of understanding of how the trauma of the oppressed is experienced and responded to at personal, institutional, national and international levels. Maybe the weight, complexity and unresolved trauma of Palestinian and Israeli peoples illustrates the limitations of adult education and struggles for peace. How much, for instance, can projects like this represent a good enough therapeutic space, with the necessary time, empathic listening and processing required? Or is there some hope in what we sought to do, given the bleak alternative of rhetorics of blame?

Our initial project included educators from Georgia, living in fragile contexts too, born, as their country was, out of the disintegration of the old Soviet Union. The spectre of Russia haunts Georgian society, with one province, South Ossetia, occupied after the 2008 War, while the integrity of the border is constantly threatened. There are ethnic tensions as Georgia seeks to modernise, giving primacy to Georgian as the national language, which is resisted by Armenian minorities in the south of the country. They of course have suffered their own massive historical traumas. But the prime focus of the present chapter is Israeli/ Palestinian/Arab Israeli dynamics and our efforts to create good enough transitional and narrative space for dialogue and mutual recognition. Elias Khoury (2019) has written that the oppressed Jew of twentieth century Europe is not simply the mirror image of the Palestinian but of every human everywhere. The Palestinian is also the mirror image of expelled and oppressed peoples in all lands. The mirror image in fact of the refugee crisis engulfing the world today. Is it possible to recognise the other-Jew or Palestinian - as traumatised, hurting, like ourselves, as a basis for dialogue? For what Bashir and Goldberg (2017) call empathic unsettlement, where our stories and assumptions are listened to and challenged, humanely, as a basis for seeing things anew.

There are of course profoundly differing perspectives on the historical and contemporary Middle Eastern situation. Both Palestinians and Jews claim the same land and arguably have valid emotional reactions to conflict, displacement and existential threat. But their personal and historical stories dramatically diverge: on the one hand, there is the narrative that in 1897 there were around half a million Arabs, Bedouins and Druze living in Palestine, with only 30,000 or so Jews. By 1935 the Jewish population comprised a quarter of the population and in 1948, Al Nakba represented, for Palestinians, ethnic cleansing of a people who were driven from their homes, land and communities in which they had lived for centuries. Here is a manifest asymmetry of power between the Israeli state, with its metropolitan pretensions, Western military guarantors, on the one hand, and displaced, stateless and colonised Palestinians on the other. Jewish people tell stories of waves of anti-Semitism, across centuries, in Europe 
and beyond, culminating with 2 out of 3 European Jews being exterminated in the Holocaust. Israeli Jews celebrate the 1948 War as one of liberation and finding security, while for Palestinians, as noted, it is the catastrophe (BaronCohen, 2019). Part of the problem however is the Holocaust tends to be cast as an historically unique event, in the dominant Jewish narrative, in effect downplaying or rejecting the significance of the Nakba altogether.

We are two seasoned practitioners using auto/biographical narrative methods over a period of years, in a search to create what we call, in the spirit of Donald Winnicott, good enough transitional and even transformational space where significant and difficult life experiences can be engaged with dialogically and relationally (see Bainbridge \& West, 2012; Formenti \& West, 2018; Dominicé, 200o; Merrill \& West, 2009; West, 1996, 2016; West, Alheit, Andersen, \& Merrill, 2007). We seek to nurture deeper forms of self/other relationship, reciprocal understanding and shared commitment to social justice. Our teaching seeks to encourage empathic, reflexive listening, respectfulness, openness, dialogue, trust, playfulness, equality and learning about self and the other. But the process is often difficult as the other's presence and story challenge our own, and we, in turn, might freeze. It is not about smoothing over this difficulty rather to name and engage with it narratively, reflexively and developmentally.

We use the metaphor of the key as allegory and symbol of hope. The inspiration is an old Sufi parable from the tales of Mulla Nasrudin (Shah, 1985). Teachers from ancient times have used allegories to nurture knowledge and insight into messy, dark, and illusive aspects of experience. There are different versions of the story but in the original the traveller is walking home late at night when he sees an anxious Mulla Nasrudin crawling on hands and knees, on the road, searching, frantically, under a streetlight. 'Mulla, what have you lost?' the passer-by asks. 'I am searching for my key', Nasrudin says worriedly. 'I'll help you look', the man says, and joins Mulla Nasrudin in the search. Soon both men are on their knees, under the streetlight, searching. After a while, the traveller asks, "Tell me Mulla, do you remember exactly where you dropped the key?' Nasrudin waves his arm back toward the darkness and says, 'Over there, in my house. I lost it there'. Shocked and exasperated, the passer-by jumps up and shouts at Mulla Nasrudin, "Then why are you searching for the key out here in the street?' 'Because there is more light here than inside my house', Mulla Nasrudin answers nonchalantly (Shah, 1985).

Superficially, the event is nonsensical. But there are different levels of meaning. People may constantly look for the key to peace, happiness, or the good 
life, or for bliss, freedom and tranquility, maybe even for love, and God, in the wrong place. They may frantically attach themselves to cults or immerse themselves in particular theories because they are popular or dominant. For a while, there can be a sense of belonging but quickly followed by disappointment. Maybe the key lies deep within, in our unconscious, and or in our biographies, cultures and suffering, but the light is hidden and the search arduous. Perhaps one educational and therapeutic key is to see the other, not as identical to ourselves, in a kind of conflation of complexity, but traumatised, too, in ways we find difficult to acknowledge. For many Israeli Jews, as noted, the Holocaust allows no comparison, everything pales in its presence. Palestinians may refuse its admission in the light of colonialist oppression, and their own pain. The world is easily divided into binaries of self and other, them and us, good and bad, violent and peaceful, to cope with trauma. Reparative work can seem too difficult in the face of the depth of all this while present Israeli politics - of downgrading the status of Arabic and of encouraging illegal settlements, for example, serve to make things worse.

The allegory however is infused by Sufi belief in the importance of a poetic sensibility in relation to difficult and disturbing aspects of the human condition and the need to cultivate greater tolerance of difference. It values inner qualities above external piety. Nasrudin is often regarded as an 'Idiot', an appellation Dervishes use in describing their Divine Madness. But he represents a rebuke to the dangers and excesses of the clerical, literal or fundamentalist mind. We need to look beyond appearances or outward show, to seek common understanding across trauma, injustice and the repressed, in and through the stories we tell. We draw in doing so on our experience as psychoanalytic psychotherapists as well as educators, entering a kind of conceptual and practical border country, between research, teaching and therapy (Bainbridge \& West, 2012). But the territory is challenging, and we risk getting out of our depth even though the experiment is worth trying against the darkening backcloth.

It should also be noted that the metaphor of the key is a symbol of hope among Palestinian peoples: of return to homes, communities and lost lands; in short, for justice and reparation. Both Israelis and Palestinians seek in fact a 'secure' homeland, and there have been many and varied attempts, internationally, over many years, to secure agreement, security and peace, if to little or no lasting avail

Although Israel has a formal representative democracy, there are deepening socio-economic, cultural, educational and religious fragmentations, which include 
the noisy emergence of an extreme ultra nationalist and Zionist religious fundamentalism. One cohort study of young people in Israel (Hexel \& Nathanson, 2010) illustrates how, in such a context, they experience a world lacking any security and clarity. Their attitudes and values are influenced by life in the State of Israel, after 62 years of its existence. They still fear their neighbours while the challenges of the financial crisis of 2008-2009, of climate change, (and no doubt now coronavirus) bear down on them. What, the authors ask, can young people rely on in the contemporary world? Who or what might inspire them? Where can security and stability be found? Who might be role-models? Finding a key to create secure, confident, assertive and empathic citizens, with the will to engage, constructively, with the other, appears daunting.

Stephen Sheps (2019) has reviewed a range of studies and suggests there to be a clear link between particular versions of Zionism and the manifest and latent racism in Israeli society. He argues that successive generations of Israeli citizens (and non-citizens) are exposed to a single historical and cultural narrative rather than a pluralistic one. This is intentionally designed to strengthen the emergent ethno-national character of Israeli democracy. Shep's own research engages a small sample of Jewish-Israeli teachers in reflecting on teaching in Israeli high school history and civics classrooms. He chronicles some of the institutionalised racism they encounter within textbooks and their students. The pedagogic space is riddled with dilemmas stemming from historical and structural conditions. Israeli teachers are forced to mediate the singular narratives within curricular materials; and any impetus they feel to teach counter-historical perspectives, and to creatively manage their own emotional responses, and students' reactions, can be frozen. Sheps states the problem in blunt terms:

As long as the nation is imagined as both Jewish and democratic, Israeli teachers will have limited potential to engage with the content and their students in order to make the classroom a space for meaningful dialogue and transformative social change. However limited this potential may be, it is imperative that teachers ... continue to address these challenges, despite the precarious and emotionally vulnerable conditions that they endure. (Sheps, 2019, p. 358)

Disillusionment with government and worsening racism render the classroom deeply problematic. Government and its agencies are aware of these issues but do not prioritise forms of education to empower citizens to question and act critically. This point is especially important with regard to Teacher Education programmes, as teachers have a pivotal role in preparing the next generation 
of citizens. But there are no official curricula committed to the promotion of active, inclusive and practical civic, democratic and environmental education, let alone engaging imaginatively with Palestinians for peace. The only curriculum content takes a technical and legal perspective on political and state structures, as well as conflict. 'CURE' was one small experiment in trying to do something different.

The CURE project was a European Union funded programme aiming to cultivate and strengthen the teaching and learning of democratic values and active citizenship in teacher education in Israel and Georgia. It was a multi-faceted programme for curriculum reform seeking to improve the level of content, teaching and learning in various institutions, while also aiming to involve students in 'Centres of Civic Engagement'. Collaboration between five colleges and universities in each of the two countries, and five European universities, including our own, offered expertise, advice, support, evaluation, and a range of workshops, for staff and students. This included, in our case, auto/biographical narrative enquiry as a resource for building mutual recognition, dialogue and hope.

Each Israeli and Georgian institution selected 3 faculty members and students to take part in each cycle of workshops. The formal aim, for us, was to provide quality training to empower participants from the partner countries to work with diversity in the classroom or research, using auto/biographical narrative methods. Our workshops included 'Arab Israelis' (who privately identified as 'Palestinians'), Israeli Jews as well as Georgians.

\subsection{Canterbury Tales: A Talking Cure?}

A brief note on auto/biographical narrative research workshops, which have been developed in Canterbury over several years. The ESREA Life History and Biography Research Network was a particular inspiration, methodologically and epistemologically. The workshop methodology has been used in varied contexts, including careers counselling, earlyyears and teacher education as well as in family support programmes in marginalised communities. The research methods have been recently used in illuminating the dynamics of racism and Islamic fundamentalism and the role of what we might call a 'democratic education' in a post-industrial, culturally divided English city (West, 2016). Pierre Dominicés (2000) work in Geneva was an important starting point for these developments. It involved an iterative process of building educational 
biographies, beginning with oral accounts of significant life experience, among professionals, and then working intensively in groups, moving towards formal presentations and written accounts. The accounts combined stories of diverse experience, with critical reflexivity and a theoretical repertoire designed to enhance professional competence and creativity.

One intention in Canterbury has been to build an interdisciplinary theoretical repertoire, drawing on psychoanalysis, especially object relations theory, ideas of 'biographicity' (Alheit \& Dausien, 2007), and critical theory, not least the work of Axel Honneth on self/other recognition (Honneth, 2007, 2009). An earlier EU financed study of non-traditional learners in various European universities, (RANLHE), of which CCCU was part, provided an opportunity to experiment with various theoretical psycho-social 'sensitising' frames, when interpreting the stories of diverse learners. The frames included Bourdieu's ideas on habitus, Honneth on self/other recognition, and Winnicott on transitional space (Finnegan, Merrill, \& Thunborg, 2014; Formenti, West, \& Horsdal, 2015). Donald Winnicott (1971) focused on the nature of transitional space and qualities of relationship, and even playfulness in self-formation, in analytic settings. For us, and Winnicott, these ideas can be applied broadly to cultural or educational experience. The latter represent an intermediate area between people, where self and narrative negotiation takes place - 'who am I, who might I be?' - if anxiety is sufficiently contained and we feel seen and legitimate in taking risks. But movement within the space, or we might call it a habitus, can be especially difficult for some - in a workshop or university seminar - as we risk exposing uncertain, vulnerable selves to the other's gaze.

Linden (West, 1996) has illustrated these processes in studies of nontraditional adult learners who enter the unfamiliar habitus of a university. At first a seminar can seem forbidding, as students wonder whether this is really for the likes of them. They worry how others might react to them, and their stories. 'Will anyone like me, or what I have to offer? Will what I do or say be liked? Maybe I don't deserve to be liked. I come from the wrong background and this will be despised'. Such feelings are psychologically primitive in the sense of being layered down in early experience; but they can be reactivated in new, anxious socio-cultural interactions where we feel exposed. Like an infant, so to speak, all over again. And yet we can find what Winnicott calls good objects - other students, a tutor or even something symbolic in a character from literature, with whom we identify and find recognition. These objects are internalised, and over time strengthen our intrapsychic dynamics, enabling us to claim space and agency. The stories we tell ourselves, and others become more assertive, legitimate, and we become less defended against others and otherness. 
Winnicott wrote that 'When I look, I am seen. So, I exist. I can now afford to look and see' (Formenti \& West, 2018, p.121). This is a view of self as contingent, relational, developmental and potentially agentic, forged in our interactions with diverse others and the symbolic world. What is inter becomes intrasubjective in processes of what is termed projective identification. Reparation, of whatever kind, is possible, given the right quality of psychocultural and relational space, where we feel seen, and can see.

These processes are deeply embodied, affective, unconscious and relational as much as cognitive. They can generate deep anxiety as we move beyond normal defensive structures and open ourselves to others. Eventually, perhaps, we learn to listen to the other and their story, however disturbing. Some of the anxiety is contained by us, as facilitators, in naming what is happening and using ground rules as benchmarks to encourage respectful, reflexive practice. We seek to build trust, openness, dialogue, listening, storytelling and nonabusive relationships. Our feedback to individuals and the group is done in manageable or digestible ways, informed by therapeutic practice. The capacity to digest, and the metaphor of feeding and being fed, and resistance to it, is an important part of the psychoanalytic lexicon.

The quality of space can represent, as indicated, a kind of border country between adult education and therapy, psyche and politics, rationality and emotionality, conscious and unconscious processes, self and other (Bainbridge \& West, 2012). A border country where we might begin to recognise what we have in common, which can be an important step in recognising the other. Axel Honneth supplements Winnicott by suggesting that processes of self/other recognition are important at the meso level, in seminar groups, for instance, when we feel accepted and belong; and at the macro level in wider cultural exchange when we may take on a leadership function for a group, which is essential for building stronger social solidarities (Honneth, 2007, 2009). Could we achieve some of this, at least, in our work with diverse educators? This at least was the theory.

So, a typical workshop includes an opening round in which people share an object of biographical meaning to them, like a photograph, poem, drawing, or piece of music. There is a theoretical and methodological introduction, an explanation and agreement over ground rules, followed by a role play of a narrative interview, in which one of us tells the other stories of learning to be citizens while the other models good narrative interview practice. We illustrate a nuanced respect for silence and giving time to the other. The whole group discusses the experience, agrees our interview protocol, and moves into small groups of four people, deliberately diverse in backgrounds. Participants interview each other and experiment with being interviewees, interviewers, and 
observers in turn. Over the course of a week, their oral material is developed into written auto/biographical accounts of becoming citizens and experiencing democratic values in lives. These written accounts are completed individually and or in small groups; everyone presents their auto/biographical writing, and finally, we consider how methods like these can be used in their own schools, colleges and universities.

The work touches the deepest sensitivities, and evoked frustration and anger among particular Palestinians. This was often expressed privately to us, as facilitators, about injustice and the difficulties of not being able to raise issues in the wider group. Power was asymmetrical, they said, and there could be negative implications back 'home' if they were seen as troublemakers. Israeli Jews held the power. The Israeli Jewish novelist, Amos Oz (Hari, 2018), likens the position of Palestinians and Israelis to two traumatised characters adrift on a piece of driftwood in a raging ocean. Each party wants the other to let go, while both desire safety and the land of ancestors, free from danger and oppression. But one party has more power to decide who lets go. The Palestinians in our groups live within the State of Israel and have learned how to remain silent, or adjust their stories to avoid danger. One Palestinian we interviewed, later, outside the programme, was born in the State of Israel. They said what we were attempting was like asking people to talk when the other held a gun to the head.

So to begin to illustrate the lived experience of the group. For ethical reasons, we have disguised aspects of small group experience and have elided and partly fictionalised material from different people in our analysis. We have sought to do justice nonetheless to the encounters, in narratively truthful ways. We want to describe, in fictionalised form, the stories of two people who were based in one small group. We observed one of them interviewing the other, and then talked to both, in depth, later and specifically interviewed two of them, auto/biographically. But the two people below represent a kind of amalgam of various experiences that we have elided to ensure, as much as we are able, confidentiality.

One of them introduced themselves as Palestinian and a Christian who worked in an Arab College of Higher Education near Nazareth. They talked about teaching and some of their own history of citizenship and activism. They and their partner held prominent positions in the community, and sought peace and reconciliation, based on justice for all. They preferred education and dialogue to hurling bombs and missiles at each other. They were active citizens, working in the field of Palestinian cultural studies, and the preservation of Palestinian history and culture mattered greatly to them. They wondered about introducing auto/biographical and narrative methods across their work 
to encourage agentic citizenship. The interviewer, who was Jewish, listened without interruption, despite some of the turmoil they later admitted to. They had served in the defence forces, as history, so to speak, met the present, and a difficult family story of forced expatriation was alluded to. We return to this below, in an auto/biographically more developed form: only so much was possible in this particular format, for reasons of time and trust.

Another Palestinian decided to opt out of the groups altogether, in any meaningful way. They were especially angry, they said to us, in a back and off-stage setting, using Goffman's (1956) dramaturgical metaphor. We knew things were not working, for this person and listened to his story, in private. Other Palestinians talked of how difficult it was to mention $\mathrm{Al} \mathrm{Nakbah} \mathrm{or} \mathrm{the} \mathrm{Israeli} \mathrm{occupa-}$ tion of 'their' land. Al Nakbah remained unrecognised in the wider Israeli State. Auto/biographical narrative work of this kind can touch deep and raw wounds while the group might not be good enough to deal with such trauma. This is dark, distressing territory and it was our responsibility to manage the group at any moment of time, and to decide what could and could not be handled. We erred on the side of caution, and made clear that no-one was obliged to say anything, and everyone had the right to remain silent and that we aspired, at least, to create a group where people worked respectfully and truthfully with one another. Silence might be the only legitimate option for some.

We tried to keep the dialogue going. We reminded everyone that the basic aspiration of auto/biographical narrative enquiry was to imagine the world through the others' eyes. But empathy is a difficult journey and can be disturbing. It may be easier to close things down when listening to someone we feel is racist, colonialist, or even a potential terrorist, and not open to us and our story (West, 2016). And if a week is a long time in politics, it may be far too brief to find the capacity to recognise each other's pain in a kind of common experience; let alone consider small reparative pedagogic acts for the classroom. Not to say that the weeks were insignificant, but we achieved less than we hoped for.

\subsection{Meaningful and Inspirational}

One person, however, who was Jewish Israeli, felt recognised and was motivated to work for peace:

For me it was a meaningful and inspirational week. I realised the significance of narrative writing that reveals the writer to herself and also generates contact and closeness among the group members. I discovered that everything in my life has a narrative, a history, a meaning: hobbies, occupations, values I believe in, and even clothes I like to wear. Through narrative writing I realized that nothing is impersonal. 
... I want to continue practicing this with myself and with my students, and ... in order to draw closer people with differing and even conflicting narratives. Precisely in a world that centres on individualism, I would like to become intimately familiar with the narratives of others, to participate in them, and to expand my own narrative thanks to narratives that differ from my own. I wish to find a way of creating a bridge between ethnic, ideological, and political groups with diverse narratives. In the next month I hope that I will facilitate a group of Arabs and Jews, a group of people with a left-wing narrative and with a right-wing narrative, and maybe also a group of ultra-Orthodox and secular Jews, and I will explore the practice of narrative therapy designated "definitional ceremony", which takes narrative writing even further, to investigate whether it is possible to participate in each other's narrative and open up to it. I am eager to see what will happen.

Another Israeli Jewish woman also felt recognised although her proposals to pedagogically experiment excluded any reference to peace:

I teach a course called Educators, Parents and the Community, so I am aware of the role and the importance of each, and of the effort necessary to bring these parties together, but the CURE program in Canterbury, where I was exposed to the experiences of people from different countries and cultures, enhanced my knowledge and awareness of civil engagement, of individuals and institutions ....

I feel that I have received "training", from professionals about the theoretical and more so the practical aspects of active citizenship and democratic sensibility, and I have been given the tools I need to work these into the fabric of my teaching. I taught a student whom I knew had begun a chess club at his school, one that had grown successfully and spread to a number of other schools, but I did not introduce this into my lesson, not seeing how this could be relevant to English. Upon return from Canterbury, we listened to this student's narrative about his chess club. And of course, the ways in which it was related to civil action, civic education and the teaching of English were numerous and relevant. It was a learning experience, from which we all benefited ...

... Upon returning to the college, I began collecting narrative data from my students, namely those who are new immigrants, for my own research, research that is now well underway. Our discussion about narrative method also brought me closer to solving a particular problem. I am ... requiring that students speak about their own language use. 
In every class, there are guaranteed to be speakers of English, Hebrew, Arabic and Russian, as well as other languages, and I believe that there is value in recognising this diversity .... Their narratives provide me not only the necessary insight I need into their linguistic backgrounds and language practices, but enable me to get to know them better as individuals .... These narratives also apply the material covered in classes to their real-life language use, and include elements that are applicable too to their own eventual language teaching experience .... I took away from my experience in Canterbury knowledge, tools and experiences that are bound to impact my teaching for many years to come. It was a privilege to participate in such a program.

There was other positive feedback, including from the Georgians. But there was silence too. Particular Palestinians, and Jews, preferred to tell their stories in the relatively safer space of an auto/biographical narrative interview, rather than in the larger group. If the space is to be therapeutic, listening and the containment of anxiety are essential. And as Molly Andrews (2007) suggests, in the context of the South African Truth and Reconciliation Commission, traumatised individuals may take months and even years to speak of certain experiences, while support is necessary both before and after telling their story. Of course, we were operating on a much smaller scale, but our experience suggested the need for a longer, better resourced programme.

\section{5}

\section{Moving On?}

We wanted to bring other groups of Palestinian educators (from the Palestinian Territory, Gaza and Israel itself), and diverse Israeli Jewish educators, to such a programme in Canterbury, in a more substantial search for dialogue and peace, using auto/biographical narrative methods over a longer period. We would seek money for this from the European Union and other possible funders. We used contacts made in a teacher education project in the West Bank, led by our University and financed by the World Bank (CCCU, 2016). We would also exploit contacts made in the workshops, and from colleagues researching the effects of trauma, for instance, in places like Gaza (Diab, Veronese, Jamei, \& Kagee, 2019). We imagined three main cycles in the developed project, modelled on the existing week-long workshop but with a longer initial phase; those participating would be expected to commit to all the cycles, including a virtual element, over two years and more. Time would be given to gathering initial auto/biographical narratives, and resources identified for providing 
therapeutic support, as appropriate. Eventually participants would move to consider curriculum experiment in their own institutions, and to undertake projects on local, family and community histories, across dislocation and oppression in the past and present. Attempts would be made to work in highly segregated situations, where walls of one kind or another separate peoples; maybe use could be made of festivals of diverse cultures and histories, exhibitions, theatre, music, dance, poetry a well as other forms of storytelling in the search for dialogue and peace.

Through experiences of community rituals, and teachings, mythopoetic or imaginal ways of knowing can serve to overcome negative images of the other and self by generating new ones (or retrieving ancient ones) derived from myth, poems and personal stories (Willis, 2005; Formenti \& West, 2018). Peter Willis (2005), and Leonard and Willis (2008) have described how film and poetry may be used to provide relevant images of an event (in this context, a significant moment during a person's life, as portrayed in film) to explore wider group consciousness and difference. The pedagogy seeks to create a good enough reflexive space for learners' individual and collective contemplation, encompassing existential, imaginal, family, community, historical and contemporary experience, including trauma. We wanted to find a key to generate a little more light and hope in the present bleakness of Israeli/Palestinian relationships.

\subsection{Walls}

But we walked into a hard metaphorical wall. We imagined bringing together groups of progressive educators from diverse backgrounds, as suggested. To tell and share stories of migration, trauma, injustice, and colonialism and to build some mutual understanding in a kind of pedagogy of interruption, unsettlement and struggle for recognition; maybe to create a shared grammar by which to talk about past, present and future - including of teaching and curriculum development - in new ways in what could become both an educational and potentially therapeutic space.

We talked with colleagues from 5 Palestinian universities involved in the West Bank Teacher Education project. They listened silently as we described our idea. 'No way', the group leader said. 'If we cooperated with these people, even if we wanted to, we would be sacked in the morning. Of course, we recognise, as Elif Shafak (2020) has recently written, the dignity of rage in the face of such injustice and oppression. But we listened to this with the noise of deteriorating relationships in the Middle East in our minds. Black (2020) suggests that this might well lead to further expropriation of Palestinian land and property, and the expulsion of individuals, families and communities from annexed territories. But who were we to challenge our Palestinian colleagues? We had known no such trauma in our lives. 
A colleague researcher who works among Palestinians wrote to us:

I was talking to you about the real absence of a dialogue between oppressed and oppressor. Perhaps, a path for change could come after a real new catastrophic event. The oppressor is trapped in a predatory narrative of denial and disqualification, looking at the indigenous people as an obstacle for realising their happiness and reparation from the crimes they experienced in their recent and ancient history as a victim. So far, the oppressor appears disgusted by an uncivilized, homophobic, and misogynistic stereotype about the oppressed; their dirty indigenous villages are disturbing the civilised white and technologically advanced world of the oppressor, they must be excluded and hidden from those civilised eyes by walls, barriers, electronically protected fences and drones that vertically (land, airspace, and underground) control the Palestinian lives. On the opposite, the oppressed envy the clean, easy and perfumed lives of the oppressor, their freedom to travel, to bathe in crystalline swimming pools, to be celebrated internationally as champions of freedom and democracy for few. The result, revivifying the Fanon metaphor, is the confrontation between two mutually excluding species - the ones of the oppressed and the oppressor. Structures of power such as settler colonialism and capitalistic agendas are making the dialogue impossible .... I guess even Paulo Freire who promoted the dialogue between oppressor and oppressed, between colonised and coloniser, black and white, man and women, will recognise that in such a condition just the monologue of violence in the confrontation between power and powerless can take place .... Listening to the mourning of the oppressed, listening to their desperation and thirst of justice, their right for self-determination and return to their land, I do think is the only way.

The message was powerful, and we pressed the pause button on the whole idea. Even Paulo Freire it was suggested, would baulk at the possibility of dialogue in a context like this. Structures of power like settler colonialism, and images of a kind of metropolitan glitter contrasting with Palestinian dirt and shabbiness, was strong language. So too was the continuing reminder of everyday violence against ordinary people in the present as well as past. But questions still nagged away: was it impossible for Israeli Jewish educators to accept that their country was engaged in violence and settler colonialism? Might they be open to the idea of an unresolved historical trauma in their own individual and collective lives played out in their own State's relationships with Palestinians? Maybe something could be achieved if their stories of family trauma, existential angst and insecurity could be acknowledged in some way 
by the other? Despite asymmetries of power and present privilege, both sets of stories need to be heard for progress to be made, on however small a scale.

We think it helpful to return at this point, to our two fictionalised characters above, participating in our workshops. In the auto/biographical narrative interviews we witnessed detailed, harrowing accounts of family and personal histories from Jews and Palestinians. One talked about the time, in their family's story, when the Jewish Hagenah (terrorists, in this perspective), came to their town, Haifa. Their parents had lived and worked there all their lives, including on the railways built by the British. The family now lives in Nazareth. They talked of a desolate, desperate search for safety, and of relatives lost, homes seized, and communities abandoned. Their family had fled to Nazareth alongside other relatives, who were escaping a village close by being ethnically cleansed'. The family imagined that Jewish forces would not enter Nazareth because it was the place of Christ's birth and there were so many churches of different denominations. Surely Jewish forces would not desecrate the place for fear of losing Western support. They were right. But in more recent times, the same Palestinian talked of a relative who lived in Gaza not been allowed to finish their degree studies in Bethlehem. In fact, they were arrested by Israeli defence forces on the way back to Gaza, handcuffed, blindfolded and left waiting for hours in a kind of ritual humiliation.

The other, an Israeli Jew, told a story of Jewish people in North Africa, from where their family had come. Zionist organisations had encouraged emigration, particularly from poorer areas to provide valuable labour. Persecution, anti-Semitism and poverty combined with an increasing identification of 'their' country with the 'Arab struggle' to provoke another kind of Jewish exodus. Security, in this instance, had an intimate face. A father was a bully, and there was constant abuse and humiliation in the family. When the family arrived in Israel, the overwhelming feeling, for one child, was 'at last there is safety'.

Later, like everyone else under compulsory conscription, they joined the military and felt recognised there and were chosen for special counter-insurgency training. They had been deployed to deal with what they saw to be 'terrorist infiltration' and might well have been responsible for the abuse of the young student from Gaza. But the new training brought abuse all over again, from sadistic authority figures, and they quit as soon as they could. What auto/ biographical narrative work could achieve is to illuminate common, insecure and painful experience, where dialogue could be born through sharing stories, witnessing these and slow, maybe at times ambivalent processes of self/other recognition. We can get to a human core, as Said terms it, beyond binaries and blame, to common suffering; and the possibility of shared, fragile humanity given a narrative airing as a basis for some learning and maybe healing too. 
The alternative is likely to be more violence, which of course, for some, is a solution of a kind, however hopeless. Franz Fanon wrote that 'naked violence ... only gives in when confronted with greater violence' (Fanon, (1963 p. 53). Fanon was educated in an impeccably French way, and his vision of terror, Tom Holland (2018) suggests, would have been familiar to Robespierre and the Committee of Public Safety. One of our interlocutors stated that there could never be meaningful dialogue without an Israeli admission of guilt as a colonial oppressor. How might our Israeli Jew relate to this challenge, without some recognition of their suffering and insecurity too? We are left with a conundrum about how people can profitably engage with the other, and the role of forgiveness and magnanimity. This is of course an age-old question about the potential of violent and nonviolent struggle, and the place of a generosity of spirit in our humanity and quest for progress and reconciliation. In the witness of Martin Luther King, Gandhi and Nelson Mandela, a life can involve trauma but alongside determined, painful and courageous recognition of the oppressor as human too.

We are aware of other grassroots projects seeking to establish greater empathy between Israelis and Palestinians, such as the Parents Circle or Family Forum and these appear to work in good enough ways (Baron-Cohen, 2019). There are women coming together and dialoguing - even when sons have been killed by the other side - in the search for peace, reconciliation and healing. Creating space for a dialogical, auto/biographical, narrative experiment in the border country of therapeutic adult education for peace could provide another key. If, as Jaqueline Rose (2017) observes, it can be too painful to traverse the passage from trauma into words and that words are not easily formed in the face of the colonialising other, there can be nonetheless a flickering auto/biographical light in which telling and sharing stories becomes more possible, while poetry, music, dance and enactment can also humanise the gaps between people.

Moreover, not all Israelis are complicit in violence and some protest and work in places like Gaza, in early years education, for instance. We have a researcher colleague involved in such international collaboration there, with some success (D. Valkanova, private communication, 2020). There are Jewish people who do recognise the continuing Palestinian pain of the Nakba, and act politically as well as educationally for peace and justice (see Bashir \& Goldberg, 2017). There could be a narrative, playful and poetic key to open a small door to small ecologies of learning and hope. It is just possible to imagine transitional space where disturbance is mutually recognised, and people feel seen, and can exist more openly and playfully together, over time; a place where shared traumas of death, forced migration and profound loss are given narrative form, and managed therapeutically as well as educationally, and where a light of peace might flicker more brightly. 


\section{References}

Alheit, P., \& Dausien, B. (2007). Lifelong learning and biography: A competitive dynamic between the macro and the micro-level of Education. In L. West, P. Alheit, A. S. Andersen, \& B. Merrill (Eds.), Using life history and biographical approaches in adult and lifelong learning (pp. 57-70). Peter Lang.

Andrews, M. (2007). Shaping history, narratives of political change. Cambridge University Press.

Bainbridge, A., \& West, L. (2012). (Eds.). Minding the gap: Psychoanalysis and education. Karnac.

Bashir, B., \& Goldberg, A. (2017). Introduction: The Holocaust and the Nakba: A new syntax of history, memory, and political thought. In B. Bashir \& A. Goldberg (Eds.), The Holocaust and the Nakba; A new grammar of trauma and history (pp. 1-42). Columbia University Press.

Baron-Cohen, S. (2019, January 27). Only empathy can break the cycle of violence. The Guardian.https://www.theguardian.com/commentisfree/2019/jan/22/empathy-cycleviolence-israel-palestine

Black, I. (2020, June 11). Israel's annexation of the West Bank will be yet another tragedy for Palestinians. The Guardian. https://www.theguardian.com/commentisfree/ 2020/jun/11/israels-annexation-of-the-west-bank-will-be-yet-another-tragedy-forpalestinians

CCCU. (2016). Website. https://www.canterbury.ac.uk/education/our-work/partnership/ international/palestine.aspx

Diab, M., Veronese, G., Jamei N. A., \& Kagee, A. (2019). The interplay of paradigms: Decolonising a psychology curriculum in the context of the siege of Gaza. Nordic Psychology, October, 183-198. https://www.tandfonline.com/doi/full/10.108o/ 19012276.2019.1675087

Dominicé, P. (2000). Learning from our lives. Jossey-Bass.

Fanon, F. (1963). The wretched of the earth. Grove Weidenfeld.

Finnegan, F., Merrill, B., \& Thunborg, C. (Eds.). (2014). Student voices on inequalities in European higher education. Routledge.

Formenti, L., \& West, L. (2018). Transforming perspectives in lifelong learning and adult education: A dialogue. Palgrave Macmillan.

Goffman, E. (1956). The presentation of self in everyday life. Edinburgh University Press.

Hari, J. (2018, December 31). A life in focus, Amos Oz, Israel literary colossus and lifelong advocate of a two state solution. The Independent. https:/www.independent.co.uk/ news/obituaries/amoz-oz-dead-israeli-writer-novelist-palestine-israel-tale-of-loveand-darkness-a8705681.html

Hexel, R., \& Nathanson, R. (2010). All of the above, identity paradoxes of young people in Israel. The third youth study of the Freidrich-Ebert-Stiftung Changes in National, 
Societal and Personal Attitudes. Freidrich-Ebert-Stiftung, Israel Office and Macro Center for Political Economics.

Holland, T. (2019). Dominion. The making of the Western mind. Little Brown.

Honneth, A. (2007). Disrespect: The normative foundations of critical theory. Polity Press.

Honneth, A. (2009). Pathologies of reason: On the legacy of critical theory. Columbia University Press.

Khoury, E. (2019). Children of the Ghetto, my name is Adam. Archipelago Books.

Leonard, T., \& Willis, P. (Eds.). (2008). Pedagogies of the imagination. Mythopoetic curriculum in educational practice. Springer.

Merrill, B., \& West, L. (2009). Using biographical methods in social research. Sage.

Rose, J. (2017). Afterword: The Holocaust and the Nakba. In B. Bashir \& A. Goldberg (Eds.), The Holocaust and the Nakba: A new grammar of trauma and history (pp. 353-361). Columbia University Press.

Said, E. W. (1994). Culture and imperialism. Virago.

Shafak, E. (2020). How to stay sane in an age of division. Welcome Collection.

Shah, I. (1985). The Subtleties of the inimitable Mulla Nasrudin. Octagon Press.

Sheps, S. (2019). History and civics education in Israel; Reflections from Israeli teachers. Critical Studies in Education, 6o(3), 358-374.

West, L. (1996). Beyond fragments, adults, motivation and higher education, a biographical analysis. Taylor and Francis.

West, L. (2016). Distress in the city: Racism, fundamentalism and a democratic education. IOE/UCL Press.

West, L., Alheit, P., Andersen, A. S., \& Merrill, B. (Eds.). (2007). Using life history and biographical approaches in adult and lifelong learning. Peter Lang.

Willis, P. (2005, July 5-7). Transformation and the inclusive heart. Mythopoetic pedagogy for an adult educator curriculum. Paper presented at the 35th Annual SCUTREA Conference. http://www.leeds.ac.uk/educol/documents/142032.htm

Winnicott, D. (1971). Playing and reality. Routledge. 